\title{
Effect of Credit Risk and Liquidity Risk on the Performance of Commercial Banks in Ghana
}

\author{
Tan ZhongMing Angelina Kissiwaa Twum* Andrew Osei Agyemang Isaac Akpemah Bathuure \\ School of Finance and Economics, Jiangsu University, 301 Xuefu Road, 212013 Zhenjiang, China
}

\begin{abstract}
In recent years, commercial banks in Ghana have seen great development in assets and profitability and have been playing increasingly important roles on national economy and social development which has become irreplaceable in a wide range. However, financial risks have been identified as the cause of hinderances to the banks' normal development and has rendered some banks to fail. In recent years, Ghana's commercial banks have faced vigorous challenges. An important setback is the collapsing and merging of commercial banks and the increment of the minimum capital requirement. The cause of these misfortunes can be attributed to the combine effect of liquidity risk and credit risk since bank managements, supervisory authorities and government overlooked their impact. The focus of this paper is to study the impact of credit risk and liquidity risk on the performance of commercial banks in Ghana. The paper studied the annual and financial reports of licensed commercial banks in Ghana over a period of 14 years. The hypotheses generated for the study was tested using the OLS regression. The results revealed a negative relationship between non-performing loans and performance (ROA). Similarly, credit ratio and loan to deposit ratio also had a negative effect on ROA of banks in Ghana. On the contrary, liquidity ratio revealed to have a positive relationship with the dependent variable. The study recommended that, Ghanaian commercial banks must adopt a general framework for liquidity risk and credit risk management to ensure avoidance or reduction in the occurrence of these risks. Control variables help to check the robustness and also explain the objectives of the study in a more precise way.
\end{abstract}

Keywords: Credit Risk; Liquidity Risk; Commercial Banks: Performance; Ghana

DOI: $10.7176 /$ RJFA/11-17-11

Publication date:October $31^{\text {st }} 2020$

\section{Introduction}

Financial institutions, especially commercial banks, play a very important role in a nation's economy. (Berger et al., 1995) defined financial institutions in precise as enterprises such as a bank whose primary function is to collect money from the public and invest it in financial assets such as stocks and bonds, loans and mortgages, leases as well as insurance policies. For the purpose of this study, emphasis is laid on commercial banks as a key example of financial institution. They accept deposits and provide financial security to their customers. The policy of commercial banks to make money results in the elastic credit system that is necessary for economic progress at relatively steady rate of growth (Ang and McKibbin, 2007). With increased pressure on banks to improve shareholders' returns, banks have to assume higher risk and manage these risks to avoid losses (Saunders and Cornett, 2011).

According to numerous researchers including (Padilla-Pérez and Ontañon, 2014, Cebenoyan and Strahan, 2004, Olalekan et al., 2018, Bülbül et al., 2019), commercial banks face diverse types of risk which include market risk, operational risk, liquidity risk, credit risk, business risk, reputational risk and systemic risk. Out of these, credit and liquidity risks are known to be the most pertinent risks in the operational activities of commercial banks. The forms of financial risk that might affect financial institutions include, the probability that borrowers' loans may not be paid on time of maturity; credit risk or depositors will suddenly withdraw their deposits; liquidity risk. However, according to (Olalekan et al., 2018), credit risk and liquidity risk are not only the most important risks that banks face, they are also unswervingly associated to the activities of banks and their causes of failure.

The 2017 Annual Report of Bank of Ghana revealed a total credit of GHф29.1 billion and GHф28.7 billion as at 2015 and 2016, respectively. In 2017 the amount recorded for Gross Credit Advances was GH $\notin 37.66$ billion which represented $1.3 \%$ reduction in the GDP growth as compared to the $1.9 \%$ increase in the previous year. In further postulation, the report showed an increase of $22.7 \%$ in the total non-performing loans of commercial banks in December 2017 as compared to a rate of $17.3 \%$ in December 2016. These figures explain the persistence collapse and merging of numerous commercial banks in Ghana. In 2017, Ghana's commercial bank with the largest asset size, GCB, through the intervention of the central bank of Ghana, took over two commercial banks with the motive to reduce the unending effect of the collapses on customers of those banks. To protect customers and restore confidence in the banking sector, the Bank of Ghana increased the minimum capital requirement from GH $\notin 120$ million to GHф400 million representing an increase 233\% (Bank of Ghana Annual Report, 2017).

Empirical studies on the Ghanaian commercial banks showed that, liquidity creation which reflects commercial banks' whole liquidity risk can significantly impact banks' performance. Also, their function as a lender to customers, broadens the probability of credit risk occurring. This paper asserts that, commercial banks 
can lower its probability of failure by strengthening banks joint risk management of liquidity and credit risks

\section{Literature Review}

\subsection{Credit Risk}

Credit risk refers to the likelihood that a contractual counterparty will not meet its obligations due to decline in repay ability or unwillingness to comply with the contract (Brown and Moles, 2014). Therefore, credit risk emerges when a bank fails to recover the lending money from a borrower or a counterparty. According to (Spuchl'áková et al., 2015), credit risk is a threat that the bank may not be able to collect the principal or interest on loans and securities as promised. Generally, loans and advances are the biggest and the most obvious cause of credit risk in the majority of banks (Okafor and Fadul, 2019). According to the Basel Accords, losses occur even when the counterparty does not breach the contract, but there will certainly be signs showing increasing probability of borrower's insolvency. Credit risk is one of the key causes of bank failure hence, if not properly managed, it may lead to insolvency and bankruptcy. Banks control credit risk through effective risk management that contains a comprehensive credit risk analysis must be based on scanning and monitoring of the most trustworthy loan applications, the degree of collateral, diversification of the loan portfolio, accurate loan pricing depending upon the borrowers' ability to repay and intentions (Flaxman et al., 2010, Mwangi and Muturi, 2016, Dykstra and Wade, 1999).

(Sadgrove, 2016), argued that the well management of credit risk can lead to effective performance which is the goal of all commercial banks. To achieve this, commercial banks must apply credit management tools and techniques that are able to help in monitoring credits and evaluating returns from the risk bearded. As banks are in business to extend credit, their level of credit risk is highly significant to their business operations. According to (Bouteille and Coogan-Pushner, 2012) of all the organizations exposed to credit risks, commercial banks have the largest credit portfolios and possess the most sophisticated risk management. However, as the financial system has undergone crises in recent years, the environment of lending has changed in response.

\subsection{Liquidity Risk}

Liquidity is the ability of a company to meet its short-term liabilities. This means that if the company must meet its obligations, the company will be able to meet the debt, especially debt that has matured. If the liquidity level of a bank is high, then the level of profitability will decrease. Conversely, if the bank is experiencing a low level of liquidity, it will lead to increased levels of profitability (Saleem and Rehman, 2011). (Saunders and Cornett, 2011) define liquidity risk as the unexpected raise in withdrawals by depositors that may pursue banks to liquidate their assets in the shortest time period. The liquidity risk arises due to several reasons including a rapid increase in the sudden demand of the bank's depositors and an inadequate market depth or market disruption (Vento and La Ganga, 2009, Ruozi and Ferrari, 2013, Awgchew, 2017).

Regarding the provision of liquidity, banks accept funds from depositors and extend such funds to the real sector while providing liquidity for any withdrawal of deposits. However, the banks' role in transforming shortterm deposits into long-term loans makes them inherently vulnerable to liquidity risk (Bank for International Settlements, 2008). A liquidity shortfall at a single bank can have system-wide repercussions. The global subprime crisis of 2007 to 2008 emphasized the importance of liquidity management in banking sector. The Basel Committee issued its "Principles for Sound Liquidity Management and Supervision which gave two concepts of liquidity, funding liquidity and market liquidity. Insufficient liquidity can gear a bank towards unexpected cash deficiencies which are needed to be covered, hence decrease profitability. It can also induce a bank towards liquidity insolvency devoid of being capital insolvent. Hence, banks face liquidity risk when they are not able to meet their expected and contingent cash needs and borrow more funds when required

\subsection{Bank Performance}

Bank performance is seen as the process of measuring the results of a bank's policies and operations in terms of monetary value. These results are reflected in the bank's profitability. Evaluating the financial performance of a bank allows shareholders to judge the results of business strategies and activities in objective monetary terms. Numerous researchers investigated that performance evaluation is one of the most important aspects of banks because the goal of any bank is to make profits. They also postulate that, there is no bank that can operate without making profit. Performance has also helped banks to determine their position at market place for competitive advantage (Brissimis et al., 2008, Goh, 2005, Barth et al., 2003, Bonin et al., 2005, Lin and Chiu, 2013). Profitability is an indicator of banks' capacity to carry risk and/or increase their capital. It indicates banks' competitiveness and measures the quality of management. Generally, ratios are used to determine the financial performance of an organization. Several studies have also found that bank sector performance is influenced by the cost to income ratio, operating expenses, and ratio of equity to total assets (Said and Tumin, 2011, Zopounidis and Kosmidou, 2008, Kosmidou et al., 2005, Petria et al., 2015). (Petria et al., 2015)pointed out that financial ratios can be used to recognize a bank's specific strengths and weakness as well as providing detailed information about 
bank profitability, liquidity and credit quality policies.

\subsection{Credit Risk and Bank Performance}

(Mwangi and Muturi, 2016) researched on the impact of financial risks on firms' performance in Kenya. The research concluded that credit risk affected lending and borrowing by financial firms, leading to unpredictable losses which affect performance. (Hosna et al., 2009) studied the relationship between non-performing loan and capital adequacy ratios and profitability for Swedish banks and the study showed that rate of non-performing loan and capital adequacy ratio were inversely related to ROE though the degrees vary from one bank to the other. Such inverse relationships between profitability, performance and credit risk measures were also found in other studies (Ogboi and Unuafe, 2013, Kargi, 2011, Crook et al., 2007, Girardone et al., 2004).

(Afriyie and Akotey, 2013) examined the impact of credit risk on the profitability of rural and community banks in the Brong Ahafo Region of Ghana. The study used Non-Performing Loans Ratio (NLPR) and Capital Adequacy Ratio (CAR) as credit indicators and revealed a significant positive relationship between nonperforming loans and rural banks' profitability revealing that, there are higher loan losses but banks still earn profit.

(Cebenoyan and Strahan, 2004)investigated the effect of credit risk management on the performance of deposit money banks using ROA, non-performing loans ratio and the ratio of total loans to total deposits as performance and credit risk management proxies, respectively. The results indicated that both variables have a significant positive influence on financial performance. (Olamide et al., 2015) employed panel linear regression to assess the impact of credit risk on financial performance for the listed banks over the period 2007 to 2011 . The findings revealed that while the non-performing loans ratio and bad debt variables have significant negative effects on financial performance of banks, the impact of credit ratio was insignificant.

Based on the above literature, the following hypotheses are developed

H1: There is a negative relationship between non-performing loans and performance of Ghanaian commercial banks.

H2: There is a negative relationship between credit ratio and performance of commercial banks in Ghana.

\subsection{Liquidity Risk and Bank Performance}

(Awgchew, 2017) analyzed the relationship between bank liquidity risk and concluded that although liquidity assets tend to gain less profit, the behavior of banks increasing liquidity assets against default or bankruptcy may lower the cost produced due to mismatching of assets and liabilities and offset the profit loss caused by owing more liquidity assets, hence there is a positive relationship between bank liquidity and profitability to some extent. But when the liquidity assets banks hold exceeds the threshold, the unused liquidity may cause idle use of bank funds, which leads to inefficiency of financial operations and investment management, and in this circumstance the relationship of liquidity and profitability becomes negative. Similarly, (Chatterjee, 2010) examined the relationship between liquidity risk of listed companies on London Stock Exchange and profitability. The research showed a negative relationship between liquidity ratio and ROA. On the contrary, (Ongore and Kusa, 2013) indicated that the relationship between liquidity risk and bank profitability in Kenya was insignificant. In addition, in the research of (Angbazo, 1997), the ratio of loans to deposits as a proxy for liquidity risk was significant and positively related to net interest margins. Also, (Petria et al., 2015) concluded in his research that, adequate level of liquidity risk is positively related with bank profitability.

With foundation built from the above literature, the hypotheses derived for this study are;

H3: The association between liquidity ratio and performance of commercial banks in Ghana is positive.

H4: There is a positive association between loan to deposit ratio of Ghanaian commercial banks and their profitability.

\section{Methodology}

This research is a causality research because it examines the influence of independent variable on the dependent variable. The population of this research included all the twenty-three (23) licensed commercial banks in Ghana. However, some banks do not provide details about the types of financing they offer to clients, especially during the time they first started. For this reason, the sample period and population were limited to only 14 years from 2005 to 2018 and 20 banks, respectively. The study population contains three different categories of Ghanaian banks such as public banks, private banks and foreign banks.

Ghana was chosen as the population because of the rampant collapse of commercial banks in the industry. Data was collected from the annual reports and financial statements of the banks as well as their official sites and that of the regulatory authorities. The data was analyzed using E-views version 12 and STATA version 15.0.

The inferential statistics was applied to establish a casual effect relating independent variables to the dependent variable. A linear regression of bank performance set against credit risk and liquidity risk was applied to establish the effect between variables. The model treats performance of commercial banks as the dependent variable while the independent variables are proxies of credit risk and liquidity risk. 
The analytical model equation is represented in the linear equation below: $\mathrm{ROA}=\alpha+\beta_{1} N P L T L_{i t}+\beta_{2} C R_{i t}++\beta_{3} L R_{i t}+\beta_{4} L D R_{i t}+\beta_{5} S I Z E+\varepsilon_{i t}$ Where ROA, denotes return on assets, NPLGL stands for non-performing loans, CR is the credit ratio, LR denotes liquidity ratio, LDR stands for loan to deposit ratio and SIZE is the total asset of the bank, $i$ represents individual bank and $t$ represents time. $\alpha$ and $\varepsilon$ represent the constant and error term, respectively.

The variables used in the analysis of this paper are summarized in Table I below.

Table 1: Summary of Study Variables

\begin{tabular}{|l|l|l|l|l|}
\hline Type of variable & Symbol & Name of variable & Explanation of Variable & $\begin{array}{l}\text { Expected } \\
\text { sign }\end{array}$ \\
\hline $\begin{array}{l}\text { Dependent } \\
\text { Variable }\end{array}$ & ROA & Return on Assets & Return on Assets & \\
\hline \multirow{4}{*}{$\begin{array}{l}\text { Independent } \\
\text { Variable }\end{array}$} & NPLTL & $\begin{array}{l}\text { Non-Performing } \\
\text { Loans }\end{array}$ & $\begin{array}{l}\text { Non-Performing Loans to Total } \\
\text { Loans }\end{array}$ & - \\
\cline { 2 - 5 } & CR & Credit Ratio & Total loans to Total Assets & - \\
\cline { 2 - 5 } & LDR & Liquidity Ratio & Total Deposits to Total Assets & + \\
\hline Control Variable & SIZE & $\begin{array}{l}\text { Liquidity to Deposit } \\
\text { Ratio }\end{array}$ & Total Loans to Total Deposits & + \\
\hline
\end{tabular}

\section{Results and Findings}

4.1 Descriptive Statistics

Table 2: Descriptive statistics

\begin{tabular}{llllll}
\hline Var. & Obs. & Mean & Std. Dev & Minimum & Maximum \\
\hline ROA & 280 & 14.1437 & 4.9072 & 3.4403 & 37.0359 \\
NPLTL & 280 & 1.1984 & 0.3775 & 0.1472 & 2.9125 \\
CR & 280 & 0.6173 & 0.1423 & 0.113 & 1.469 \\
LR & 280 & 1.4891 & 0.5294 & 0.0827 & 3.7361 \\
LDR & 280 & 0.6752 & 0.0583 & 0.0094 & 1.0838 \\
SIZE & 280 & $3.49 \mathrm{E}+11$ & 0.8261 & $2.77 \mathrm{E}+10$ & $8.76 \mathrm{E}+13$ \\
\hline
\end{tabular}

The mean ROA for the sampled banks for the period was 14.1437 with a maximum of 37.0359 and minimum of 3.4403. This indicates that on the average, Ghanaian commercial banks make a return of GHS 141.437 for every specific amount of investment made in assets. The maximum ROA of 37.0359 and the minimum of 3.4403 means that, commercial banks could earn a maximum return of GHS 370.40 and a minimum of GHS34.40 for investing into assets. The standard deviation of 4.9072 shows that, the dispersion of the performance of commercial banks is relatively low.

From Table 2 above, Non-Performing Loans recorded a mean of 1.1984. This means that, an average of $11.98 \%$ of every total loan issued will not perform as expected. The minimum and maximum values for NPLTL were 0.1472 and 2.9125 , respectively. This indicates that, on the least, $1.4 \%$ of total loans issued by Ghanaian commercials banks do not perform. Also, a percentage as high as $29 \%$ of total loans issued are rendered as nonperforming. This signifies the presence of high ratio of non-performing loans in the Ghanaian banking industry hence, the low performance of commercial banks. With a standard deviation of 0.3775 , the dataset of NPLTL is narrowly dispersed.

On average, the credit ratio recorded a mean of 0.6173 with a minimum and maximum of 0.0130 and 1.4690 , respectively. This shows that, on average, about $60 \%$ of total assets of commercial banks in Ghana are tied up in loans. Also, the highest ratio of assets used as loans is $146 \%$ with the lowest being $0.13 \%$. In effect, it can be said that, Ghanaian commercial banks hold less assets and issue more loans. A standard deviation of 0.142 implies that, $\mathrm{CR}$ is widely dispersed.

Liquidity ratio which indicates how much of the asset base is funded with core deposits recorded a mean of 1.4891. This means that, averagely, commercial banks' funds include about $14 \%$ of deposits made. The minimum and maximum values were 0.0827 and 3.736. It can be interpreted that, the lowest proportion of commercial banks deposits used as assets is $0.83 \%$ with highest being $37.36 \%$. Liquidity ratio scored a standard deviation of 0.0583 indicating a low distribution of the ratio.

The average value of Loan to Deposit Ratio was 0.6752 indicating that, about $67.52 \%$ of Ghanaian commercial banks' deposit structure funds the loan portfolio. A maximum and minimum values of 1.5838 and 0.0094 respectively were also recorded as well as a standard deviation of 0.0583 . 


\begin{tabular}{|c|c|c|c|c|c|c|}
\hline VAR. & ROA & NPLTL & CR & LR & LDR & SIZE \\
\hline $\mathrm{ROA}$ & 1.0000 & & & & & \\
\hline NPLTL & -0.2910 & 1.0000 & & & & \\
\hline $\mathrm{CR}$ & -0.1584 & 0.0952 & 1.0000 & & & \\
\hline LR & 0.2798 & -0.0089 & 0.1920 & 1.0000 & & \\
\hline LDR & -0.1140 & -0.0342 & -0.1723 & 0.2790 & 1.0000 & \\
\hline SIZE & 0.3887 & 0.1348 & -0.2058 & -0.3345 & 0.2640 & 1.0000 \\
\hline
\end{tabular}

The correlation matrix shown in Table 3 above demonstrates in pairs, the relationship between all the study variables used in the regression model. It reveals that, Non-Performing Loans (NPLTL), Credit Ratio (CR) and Loan to Deposit Ratio (LDR) have a negative relationship with the dependent variable, while all the other explanatory variables have a positive correlation with the dependent variable. The negative correlations imply that, Non-Performing Loans (NPLTL), Credit Ratio (CR) and Loan to Deposit Ratio (LDR), the performance of commercial banks also decreases and vice versa. On the other hand, the positive relationship means that, as Liquidity Ratio (LR) and Bank Size (SIZE) increase, performance of the banks increases as well.

4.3 Cross-sectional Analysis

Table 4: Cross-Sectional Analysis

\begin{tabular}{lllll}
\hline & Breusch-Pagan LM & Pesaran scaled LM & Bias-corrected scaled LM & Pesaran CD \\
\hline ROA & $205.5201 * * *$ & $23.8376^{* * *}$ & $18.2996^{* * *}$ & $25.3045^{* * *}$ \\
NPLTL & $257.2840^{* * *}$ & $10.1904 * * *$ & $9.7679 * * *$ & $6.4694 * * *$ \\
CR & $1095.1935^{* *}$ & $40.7360^{* *}$ & $39.2278^{* *}$ & $26.3204 * *$ \\
LR & $1101.5630 * * *$ & $31.3421^{* * *}$ & $29.3478^{* * *}$ & $20.5731^{* * *}$ \\
LDR & $401.3224 * * *$ & $5.5732^{* * *}$ & $3.8937 * *$ & $2.4826^{* * *}$ \\
SIZE & $2996.3894 * *$ & $119.0231 * *$ & $130.6290^{* *}$ & $46.1573 * *$ \\
\hline
\end{tabular}

$* * *, * *, *$ denote $1 \%, 5 \%$ and $10 \%$ significant level respectively

This research used Breusch-Pagan LM, Pesaran scaled LM, Bias-corrected scaled LM, and Pesasan CD to analyze the cross-sections existing among the study variables and the results are presented in Table 4 above. The results showed that, all the variables were statistically significant at $1 \%$ level throughout the test with the exception of credit ratio (CR) and bank size (SIZE) which were significant at 5\% level. Therefore, this study can be concluded to have cross-sectional dependency among the variables. Meaning, an occurrence in any of the variables will spread to others if not controlled.

4.4 Stability Test

Table 5: CIPS Unit Root Test

\begin{tabular}{lll}
\hline & \multicolumn{2}{c}{ Level } \\
Variable & Constant & Trend \& Cons. \\
\hline ROA & -2.984 & -2.965 \\
NPLTL & -3.579 & -4.775 \\
CR & 2.642 & -3.698 \\
LR & -3.043 & -2.844 \\
LDR & -2.562 & -3.544 \\
SIZE & -2.646 & -3.910 \\
\hline
\end{tabular}

An observation from Table 5 above reveals that, all the values of the variables were greater than their critical value for both constant and trend and constant. Hence, the study variables were integrated at level and the null hypothesis of no unit root is rejected. 
4.5 Multiple Regression Analysis

Table 6: Multiple Regression Analysis

\begin{tabular}{lll}
\hline Variables & Coefficient & P-Value \\
\hline NPLTL & -0.2129 & 0.0000 \\
CR & -0.5720 & 0.0290 \\
LR & 0.1298 & 0.0020 \\
LDR & -0.0204 & 0.0433 \\
SIZE & 0.3182 & 0.0724 \\
CONS & -0.8018 & 0.3973 \\
R-Squared & 0.6432 & \\
F-Statistics & 0.0000 & \\
Observations & 280 & \\
\hline
\end{tabular}

Table 5 presents the multiple regression results for the study variables. The value for R-squared (R2) of recorded was 0.6432 or $64 \%$. This implies that, the model has a higher explanatory power and that the variation in the dependent variable is best explained by the model. Moreover, F-statistic value recorded was 0.0000 which means that, the model is fit to explain the effect of credit risk and liquidity risk on bank performance of commercial banks in Ghana.

The results revealed a negative relationship between Non-Performing Loans (NPLTL) and the performance of Ghanaian commercial banks. This means that as NPLTL increases, bank performance decreases in return. In other words, higher amount of default loans is associated with larger probability of banks underperforming which may result into banking failures. This result may be due to the fact that higher loan rates are caused by higher credit risk demand.

Furthermore, credit ratio (CR) also showed a negative correlation with the dependent variable. This means that, a unit increase in CR will reflect in a decrease in the rate of performance of commercial banks.

On the contrary, liquidity ratio (LR) has a positive and statistically significant impact on bank performance. This result suggests that as liquidity increases, banks performance also increases.

Generally, liquid assets enable banks to overcome any problem of unexpected money withdrawal which may affect the overall banking performance if the bank is not holding sufficient liquid assets that could be transformed into cash immediately and at a low cost.

The effect of the loan to deposit ratio (LDR) on the performance of commercial banks is found to be negative and statistically significant at 5\% level. This effect implies that, a unit increase in LDR will result into a decrease in the performance of commercial banks. This result suggests that, commercial banks lend out more loans from the deposits made by customers. This in effect increases borrowings and decreases the level of deposits, meaning, the banks may not have enough liquidity to cover any unforeseen fund requirements.

\subsection{Discussion}

Commercial bank risk refers to a commercial bank's business activities, which due to the influence of unpredictable factors in advance, causes the actual income of the commercial bank to deviate from the expected return, and thus suffer the possibility of economic loss or hunting for additional gains. The risk of a commercial bank is directly proportional to its return. The higher the risk, the greater the probability of suffering economic losses, but the possibility of obtaining excess profits also increases. The risk of commercial banks can be related to various types of business operations. The interaction of complex factors makes the economic system form a mechanism of selfregulation and self-balance.

Credit risk and liquidity risk are types of commercial bank risks that play a pivotal role in the determination of the performance of the banks. Compared with other commercial bans risks such as market risk, interest rate risk and operational risk, liquidity risk and credit risk have more complicated and extensive causes and are usually regarded as a comprehensive risk. In addition to the imperfect liquidity and credit plan of commercial banks, management deficiencies in risk areas such as market and operations can also lead to insufficient liquidity and default loans of commercial banks and even trigger risk proliferation, resulting in the emergence of the entire financial system.

The results from the multiple regression depicts the effect of liquidity risk and credit risk on the performance (ROA) of Ghanaian commercial banks. The findings revealed a significant and negative relationship between nonperforming loans and performance. This result is an indication that non-performing loans and performance of commercial banks in Ghana have an inverse relationship. That is to say increases in non-performing loans will reduce the performance of commercial banks in Ghana. Hence, the first hypothesis of this research is accepted and this is in affirmation with the study of (Hosna et al., 2009).

The credit ratio of a commercial bank which portrays the proportion of deposit used to fund customer loans had a negative but significant effect on performance. As a measure of credit risk, this relationship implies that, credit ratio has a direct impact on the performance of commercial banks in Ghana through credit risk. The finding 
of this study is in line with that of (Javaid et al., 2011) but contrary to that of (Stephen et al., 2015). Similarly, the second hypothesis of the research is also accepted.

The results from the multiple regression showed a positive relationship between liquidity ratio and bank performance. As a measure of the probability of the occurrence of liquidity risk, liquidity ratio must have a direct and positive relationship with bank performance. This significant relationship reflects the availability of enough liquid funds for banks in events bank runs. In effect, the performance of banks increases as liquidity ratio also increases. Hypothesis 3 of this study is accepted and it agrees with the research of (Muriu, 2011).

The explanatory variable, loan-to-deposit ratio was found to have a statistically significant but negative association with bank performance. This indicates that, as LDR increases, commercial banks' performance decreases in relation. As a liquidity risk indicator, the result of the fact that commercial banks burdened with much liquidity risk is most likely to have liquidity challenges which can affect its performance. The findings of the study are consistent with the findings of (Mansur et al., 1993) and (Mohammed, 2012).

Liquidity risk mainly arises from banks' inability to cope with liquidity difficulties caused by falling liabilities or increasing assets while credit risk occurs as a result of default in the payment of principal loans as well as interest in due time. When a bank lacks liquidity, it cannot rely on the growth of debt or the rapid realization of assets at a reasonable cost to obtain sufficient funds, which will affect its performance. In extreme cases, insufficient liquidity can lead to bank failures. When commercial banks have insufficient liquidity, they cannot quickly reduce liabilities or realize assets to obtain sufficient funds at a reasonable cost, which will affect their profitability and, in extreme cases, will lead to insolvency of commercial banks. As the intermediary of depositors and borrowers, the current assets held by commercial banks at any time for payment only account for a small part of the total liabilities. If a large number of debtors of a commercial bank simultaneously default in repaying their loans, commercial banks may face credit and liquidity crisis.

\section{Conclusion and Recommendation}

The recent global recession started as a credit problem and manifested swiftly as a critical problem, resulting from liquidity risk. The key finding arising from the financial meltdown was the exposure of the ineffective and incompetent management of liquidity risk and credit risk. Management of commercial banks totally underestimated the impact these risks would have on their balance sheets, prompting governments to intervene and regulators to revisit regulations pertaining to financial institutions in general and to banks in particular. There is a joint influence of the interaction between liquidity risk and credit risk on banking performance. The effect of liquidity risk is especially harmful to the stability of banks when the credit risk is high, and vice versa. In addition, banks with lower liquidity risk relative to the ones with higher liquidity risk charge higher banking stability as their credit risk increases. This is because, sufficient liquidity enables these banks to maintain their performance and stability.

The major aim of this research was to find empirical evidence of the degree to which liquidity risk and credit risk affect the performance of commercial banks in Ghana. Based on the research findings, it was concluded that, there is an effect of liquidity risk and credit risk on performance of commercial banks in Ghana as measured by or ROA, where the relationship between the proxies of credit risk, non-performing loans (NPLTL) and credit ratio (CR) and performance is negative. Also, the relationship between liquidity risk and performance was seen to be an indecisive one, since its indicators revealed both positive and negative relationships. Liquidity ratio (LR) had a positive relationship when measured by ROA and the effect of loan to deposit ratio was negative as measured by ROA. This negative effect is due to the increased volume of untapped deposits at the Ghanaian commercial banks. Thus, a bank needs to maintain adequate liquidity, which greatly affects profits.

It is therefore recommended that, excess liquidity available at the banks be invested in order to increase the banks' profitability and to get benefits from the time value of the available money. Also, the Ghanaian commercial banks must adopt a general framework for liquidity risk and credit risk management to ensure avoidance or reduction in the occurrence of these risks. Control variables help to check the robustness and also explain the objectives of the study in a more precise way. The control variable used in this research is the SIZE.

\section{References}

AFRIYIE, H. O. \& AKOTEY, J. O. 2013. Credit risk management and profitability of rural banks in the Brong Ahafo region of Ghana. management, 5, 24.

ANG, J. B. \& MCKIBBIN, W. J. 2007. Financial liberalization, financial sector development and growth: evidence from Malaysia. Journal of development economics, 84, 215-233.

ANGBAZO, L. 1997. Commercial bank net interest margins, default risk, interest-rate risk, and off-balance sheet banking. Journal of Banking \& Finance, 21, 55-87.

AWGCHEW, S. 2017. Assessment of Liquidity Risk Management Practices \& Challenges (The Case of Private Commercial Banks in Ethiopia). St. Mary's University.

BARTH, J. R., NOLLE, D. E., PHUMIWASANA, T. \& YAGO, G. 2003. A cross-country analysis of the bank 
supervisory framework and bank performance. Financial Markets, Institutions \& Instruments, 12, 67-120.

BERGER, A. N., HERRING, R. J. \& SZEGÖ, G. P. 1995. The role of capital in financial institutions. Journal of Banking \& Finance, 19, 393-430.

BONIN, J. P., HASAN, I. \& WACHTEL, P. 2005. Bank performance, efficiency and ownership in transition countries. Journal of banking \& finance, 29, 31-53.

BOUTEILLE, S. \& COOGAN-PUSHNER, D. 2012. The handbook of credit risk management: originating, assessing, and managing credit exposures, John Wiley \& Sons.

BRISSIMIS, S. N., DELIS, M. D. \& PAPANIKOLAOU, N. I. 2008. Exploring the nexus between banking sector reform and performance: Evidence from newly acceded EU countries. Journal of Banking \& Finance, 32, 2674-2683.

BROWN, K. \& MOLES, P. 2014. Credit risk management. K. Brown \& P. Moles, Credit Risk Management, 16.

BÜLBÜL, D., HAKENES, H. \& LAMBERT, C. 2019. What influences banks' choice of credit risk management practices? Theory and evidence. Journal of Financial Stability, 40, 1-14.

CEBENOYAN, A. S. \& STRAHAN, P. E. 2004. Risk management, capital structure and lending at banks. Journal of Banking \& Finance, 28, 19-43.

CHATTERJEE, S. 2010. The impact of working capital management on the profitability of the listed companies in the London stock exchange. Available at SSRN 1587249.

CROOK, J. N., EDELMAN, D. B. \& THOMAS, L. C. 2007. Recent developments in consumer credit risk assessment. European Journal of Operational Research, 183, 1447-1465.

DYKSTRA, D. R. \& WADE, P. M. 1999. Lender direct credit evaluation and loan processing system. Google Patents.

FLAXMAN, D. R., TANTOCO-HOBBS, M. L., KOBUS, A. M. M., KOCH, M. W., PACKER, D., PLOFCHAN, P. G. \& POMEROY, R. C. 2010. System and method for processing a loan. Google Patents.

GIRARDONE, C., MOLYNEUX, P. \& GARDENER, E. P. 2004. Analysing the determinants of bank efficiency: the case of Italian banks. Applied Economics, 36, 215-227.

GOH, P. C. 2005. Intellectual capital performance of commercial banks in Malaysia. Journal of intellectual capital.

HOSNA, A., MANZURA, B. \& JUANJUAN, S. 2009. Credit risk management and profitability in commercial banks in Sweden. rapport nr.: Master Degree Project 2009: 36.

JAVAID, S., ANWAR, J., ZAMAN, K. \& GAFOOR, A. 2011. Determinants of bank profitability in Pakistan: Internal factor analysis. Mediterranean Journal of Social Sciences, 2.

KARGI, H. S. 2011. Credit risk and the performance of Nigerian banks. Ahmadu Bello University, Zaria.

KOSMIDOU, K., TANNA, S. \& PASIOURAS, F. Determinants of profitability of domestic UK commercial banks: panel evidence from the period 1995-2002. Money Macro and Finance (MMF) Research Group Conference, 2005. 1-27.

LIN, T.-Y. \& CHIU, S.-H. 2013. Using independent component analysis and network DEA to improve bank performance evaluation. Economic Modelling, 32, 608-616.

MANSUR, I., ZANGENEH, H. \& ZITZ, M. S. 1993. The association between banks' performance ratios and market-determined measures of risk. Applied Economics, 25, 1503-1510.

MOHAMMED, F. 2012. Impact of corporate governance on banks performance in Nigeria. Journal of Emerging Trends in Economics and Management Sciences, 3, 257-260.

MURIU, P. 2011. Microfinance Profitability: Does financing choice matter. Np, May.

MWANGI, B. W. \& MUTURI, W. 2016. Effects of credit risk management on loan repayment performance of commercial banks in Kenya. International Academic Journal of Economics and Finance, 2, 1-24.

OGBOI, C. \& UNUAFE, O. K. 2013. Impact of credit risk management and capital adequacy on the financial performance of commercial banks in Nigeria. Journal of emerging issues in economics, finance and banking, 2, 703-717.

OKAFOR, A. \& FADUL, J. 2019. Bank Risks, Regulatory Interventions and Deconstructing the Focus on Credit Risk. Research Journal of Finance and Accounting, 10.

OLALEKAN, L. I., OLUMIDE, M. L. \& IROM, I. M. 2018. FINANCIAL RISK MANAGEMENT AND THE PROFITABILITY: AN EMPIRICAL EVIDENCE FROM COMMERCIAL BANKS IN NIGERIA. Samuel Analyst Journal of Management Sciences, 16, 56-67.

OLAMIDE, O., UWALOMWA, U. \& RANTI, U. O. 2015. The Effect of Risk Management on Bank's Financial Performance in Nigeria. Journal of Accounting and Auditing, 2015, 1.

ONGORE, V. O. \& KUSA, G. B. 2013. Determinants of financial performance of commercial banks in Kenya. International journal of economics and financial issues, 3, 237-252.

PADILLA-PÉREZ, R. \& ONTAÑON, R. F. 2014. Commercial bank financing for micro-enterprises and SMEs in Mexico. Cepal Review, 2013, 7-21.

PETRIA, N., CAPRARU, B. \& IHNATOV, I. 2015. Determinants of banks' profitability: evidence from EU 27 
banking systems. Procedia economics and finance, 20, 518-524.

RUOZI, R. \& FERRARI, P. 2013. Liquidity risk management in banks: economic and regulatory issues. Liquidity Risk Management in Banks. Springer.

SADGROVE, K. 2016. The complete guide to business risk management, Routledge.

SAID, R. M. \& TUMIN, M. H. 2011. Performance and financial ratios of commercial banks in Malaysia and China. International Review of Business Research Papers, 7, 157-169.

SALEEM, Q. \& REHMAN, R. U. 2011. Impacts of liquidity ratios on profitability. Interdisciplinary journal of research in business, 1, 95-98.

SAUNDERS, A. \& CORNETT, M. M. 2011. Financial markets and institutions, McGraw-Hill Education.

SPUCHLÁKOVÁ, E., VALAŠKOVÁ, K. \& ADAMKO, P. 2015. The credit risk and its measurement, hedging and monitoring. Procedia Economics and Finance, 24, 675-681.

STEPHEN, F., DJAN, G. O., BAWUAH, J., HALIDU, O. B. \& KUUTOL, P. K. 2015. Impact of Corporate Governance Mechanisms and Banks Performance: Ghanaâ€ ${ }^{\mathrm{TM}} \mathrm{s}$ Position. International Journal of Empirical Finance, 4, 324-335.

VENTO, G. A. \& LA GANGA, P. 2009. Bank liquidity risk management and supervision: which lessons from recent market turmoil. Journal of Money, Investment and Banking, 10, 78-125.

ZOPOUNIDIS, C. \& KOSMIDOU, K. 2008. The determinants of banks' profits in Greece during the period of EU financial integration. Managerial finance. 